
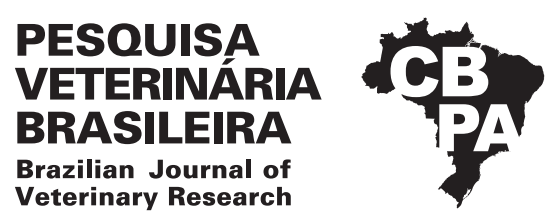

Pesq. Vet. Bras. 39(8):663-667, August 2019 DOI: 10.1590/1678-6160-PVB-6228

Original Article

Animal Morphophysiology

ISSN 0100-736X (Print)

ISSN 1678-5150 (Online)

\title{
B-mode ultrasonography and gray scale histogram for evaluation of the nuchal ligament in Quarter horse ${ }^{1}$
}

\author{
Wildemberto A. Santos ${ }^{2}$, Michel C. Vettorato², Jéssica L. Fogaça ${ }^{2}$ (D), \\ Nayara M.G. Mazzante ${ }^{2}$, Fernanda G. Oliveira² ${ }^{2}$ Guilherme P. Nogueira ${ }^{3}$, \\ Maria C.R. Luvizotto ${ }^{3}$ and Vânia M.V. Machado²* (1)
}

\begin{abstract}
Santos W.A., Vettorato M.C., Fogaça J.L., Mazzante N.M.G., Oliveira F.G., Nogueira G.P., Luvizotto M.C.R. \& Machado V.M.V. 2019. B-mode ultrasonography and gray scale histogram for evaluation of the nuchal ligament in Quarter horse. Pesquisa Veterinária Brasileira 39(8):663-667. Departamento de Reprodução Animal e Radiologia Veterinária, Faculdade de Medicina Veterinária e Zootecnia, Universidade Estadual Paulista "Julio de Mesquita Filho", Rua Prof. Dr. Walter Mauricio Correra s/n, Rubião Junior, Botucatu, SP 18618-970, Brazil. E-mail: vania.mv.machado@unesp.br

The gray scale histogram (GSH) makes it possible to measure the amount and distribution of gray shade frequencies, providing quantitative information on both echogenicity and echotexture of tissues. There is a need to diminish the subjectivity of the ultrasound images of the nuchal ligament (NL). This work proposes to evaluate the NL by ultrasound B-mode GSH images in different ages of Quarter horses. It used 15 healthy Quarter horses, which were classified by age into three different groups: "baby" (1), "sobreano" (2) and "adult" (3). The animals were submitted to chemical restraint for the ultrasound examination. Subsequently, the GSH tool was used in each image for statistical analysis. There was a significant difference between Mean and Mode between groups. Group 1 differed significantly when compared to Group 2 and 3. Group 2 presented superior echogenicity to Group 1 and 3. The height of the NL did not vary considerably between groups. GSH indicated that the echogenicity of NL in Quarter horses varies with age.
\end{abstract}

INDEX TERMS: B-mode, ultrasonography, gray scale histogram, nuchal ligament, histogram, equine, Quarter Horse, morphology.

RESUMO.- [Ultrassonografia modo-B e histograma em escala de cinza para avaliação do ligamento nucal em equinos da raça Quarto de Milha.] 0 histograma em escala de cinza (HEC) possibilita a mensuração da quantidade e distribuição da frequência de tonalidades de cinza, fornecendo informações quantitativas, tanto sobre a ecogenicidade quanto a ecotextura dos tecidos. Havendo a necessidade de diminuir a subjetividade das imagens ultrassonográficas do ligamento nucal (LN), esse trabalho propôs avaliar o LN por imagens ultrassonograficas

\footnotetext{
${ }^{1}$ Received on February 12, 2019.

Accepted for publication March 20, 2019.

${ }^{2}$ Departamento de Reprodução Animal e Radiologia Veterinária, Faculdade de Medicina Veterinária e Zootecnia (FMVZ), Universidade Estadual Paulista "Julio de Mesquita Filho" (Unesp), Distrito de Rubião Junior s/n, Botucatu, SP 18618-970, Brazil. *Corresponding author: vania.mv.machado@unesp.br

${ }^{3}$ Faculdade de Medicina Veterinária de Araçatuba, Universidade Estadual Paulista "Julio de Mesquita Filho" (Unesp), Rua Clóvis Pestana 793, Dona Amélia, Araçatuba, SP 16050-680, Brazil.
}

modo-B pelo HEC em diferentes idades de cavalos da raça Quarto de Milha. Utilizou 15 cavalos da raça Quarto de Milha saudáveis os quais foram classificados por idade em três grupos diferentes: "baby" (1), "sobreano" (2) e "adulto" (3). Os animais foram submetidos a contenção química para a realização do exame ultrassonográfico. Posteriormente, a ferramenta HEC foi empregada em cada imagem para análise estatística. Houve diferença significativa entre as variáveis "Mean" e "Mode" entre os grupos. 0 Grupo 1 diferenciou significativamente quando comparado ao Grupo 2 e 3. 0 Grupo 2 apresentou ecogenicidade superior ao Grupo 1 e 3. Quanto à altura do LN não teve variação considerável entre os grupos. 0 HEC indicou que a ecogenicidade do LN em cavalos Quarto de Milha varia conforme a idade.

TERMOS DE INDEXAÇÃO: Ultrassonografia, modo-B, histograma escala de cinza, avaliação, ligamento nucal, equinos, Quarto de Milha, morfologia. 


\section{INTRODUCTION}

Equines are animals with great physical ability and well-developed bone and muscle structures. Their dynamics result from the combined movement of each individual vertebra and is limited by the presence of different adjacent structures, such as muscles, ligaments, invertebral joints, and ribs (Getty 1975, König \& Liebich 2013).

Traumatic head injuries are common in horses, especially in foals and younger individuals, as several health conditions cause traumas in this region (Ragle 1993, Ramirez et al. 1998, Swarbrick et al. 2018). In such circumstances, a clinical examination must be carried out to diagnose the conditions affecting this region at different ages.

The nuchal ligament (NL) is an elastic structure located in the posterior midline of the spinous process between the occipital crest and cervical vertebrae (Gellman \& Bertram 2002). This structure can be affected by health conditions such as desmitis, calcification, and spondylosis. In addition, the morphology and distribution of these lesions support a pathogenesis where developmental abnormalities with potential biomechanical impact on the cervical spine contribute to cervical stenotic myelopathy in horses (Janes et al. 2015). Two-dimensional ultrasound imaging (B-mode) allows for a precise evaluation of this region (Henson 2013).

Detailed anatomy of equines has received little attention, especially ligaments. Thus the need for studies that aim to broaden the knowledge on the normal and pathological characterization of the neck ligaments, allowing for early and accurate diagnosis (Ragle 1993, Ramirez et al. 1998, Gollob et al. 2002).

Ultrasound imaging combined with grayscale histogram (GSH) allows the measurement of the amount and distribution of the frequency of gray levels, providing quantitative information (Osawa \& Mori 1996). According to Ferreira \& Rasband (2012), the ultrasound images are made up of pixels numerically represented on a scale of 255 gray levels varying according to their brightness, where $0=$ black (hypoechoic) and 255=white (hyperechoic).

Tsukiyama et al. (1996) pointed out that GSH analysis is efficient for evaluation of tendons, and Hsu et al. 2017), of ligaments. Ultrasound findings are subjective and produce many discrepancies either due to the ultrasound system variability or to the operator's experience. The GSH can help in diagnostics interpretation and has become an increasingly used tool both in clinical routine and in research (Osawa \& Mori 1996, Ferreira \& Rasband 2012, Silva et al. 2015, Fogaça 2018, Castiglioni et al. 2018).

The GSH tool can help evaluate this structure and reduce the subjectivity of NL ultrasound images, as studies on equines are scarce in the literature reviewed. Therefore, this work aims to assess the NL by means of B-mode ultrasound and GSH images in American Quarter horses of different ages.

\section{MATERIALS AND METHODS}

This study has been approved by the Animal Research Ethics Committee (CEUA) of "Faculdade de Medicina Veterinária e Zootecnia" (FMVZ) of "Universidade Estadual Paulista 'Júlio de Mesquita Filho'” (Unesp), Botucatu campus, under protocol number 0182/2016.

This study included 15 healthy horses of the American Quarter horse breed. The animals were randomized and classified into three different groups by age. Group 1 included five post-weaning animals under one year of age (foals). Group 2 included five halter-broke animals above one year of age (colts), and Group 3, five animals above three years of age undergoing taming (adults). Groups 1, 2 and 3 were 8, 20 and 39 months old, on average, and presented a mean body mass of $238 \mathrm{~kg}, 389 \mathrm{~kg}$ and $462 \mathrm{~kg}$, respectively.

The inclusion criteria were based on the age and body weight. The procedures were performed in a private property located in the city of Bilac, State of São Paulo, Brazil. The horses were placed in an individual constraint pen, where good animal welfare was observed. The only group requiring anesthesia was Group 1, as its members were not halter-broke yet.

Animals in Group 1 were sedated with alpha 2-adrenoceptor agonists xylazine and detomidine. The sedation was reverted after the ultrasound scan using the alpha 2-adrenoceptor antagonist, yohimbine. The following dosages were administered: 0.1-0.2 milligrams per kilogram of body weight $(\mathrm{mg} / \mathrm{kg}$ ) of xylazine, $0.02 \mathrm{mg} / \mathrm{kg}$ of detomidine, and $0.125-0.250 \mathrm{mg} / \mathrm{kg}$ of yohimbine, in accordance with the literature (Guedes \& Natalini 2002, Melo et al. 2007, Marques et al. 2009).

The ultrasonography was performed on a SonoScape ultrasound system model A6 and a linear transducer with a frequency bandwidth of 7.5-8.5 megahertz (MHz) and gain at $180.50 \%$ isopropyl alcohol ( $50 \%$ water, $50 \%$ alcohol) was used prior to the application of the ultrasound gel.

The animals in Group 1 had not experienced the interference of haltering--their only contact with men was for feeding, hoof trimming (in case of congenital defects affecting balance), pulverization and administration of vermifuges. The foals were guided through a handling pen (corridor placed inside the corral to take the animal to the examination pen) and constrained by the keeper. Following constraint, they were weighted and sedated.

The animals in Group 2 and 3 were taken to the examination pen by a guide. They were neither sedated nor physically immobilized in addition to the pen and halter. The most comfortable head position for the animals was allowed; however, all of the animals kept their head above the withers, which became a standard position.

Three images were taken for each animal and assessed by three technicians. The interobserver correlation was evaluated by means of an analysis of the Mean values found. Afterwards, a GSH analysis was performed on the ultrasound images on software ImageJ (National Institutes of Health), in order to quantitatively represent echogenicity in each image.

The GSH measurements were performed on an area of $2 \times 5 \mathrm{~cm}$ circumscribed at the center of the NL image. An interval from 1,000 to 1,500 pixels was considered for sample collection within the area circumscribed.

The Mean and Mode values were obtained (Fig.1). Following this procedure, the NL height was measured by the same software, where 35 pixels per centimeters was the area considered for measurement (Fig.2). The data were inserted into a Microsoft Excel 2013 spreadsheet for statistical analysis.

Statistical analysis was performed using GraphPad Prism 7 software to evaluate the variables of interest. An ANOVA was applied with a level of significance of $5 \%(p<0.05)$ for differences among groups with post-hoc Tuckey.

\section{RESULTS}

Table 1 shows the mean and standard deviation of the GSH variables (Mean and Mode) followed by the ANOVA p-value for the NL of the three groups evaluated. 


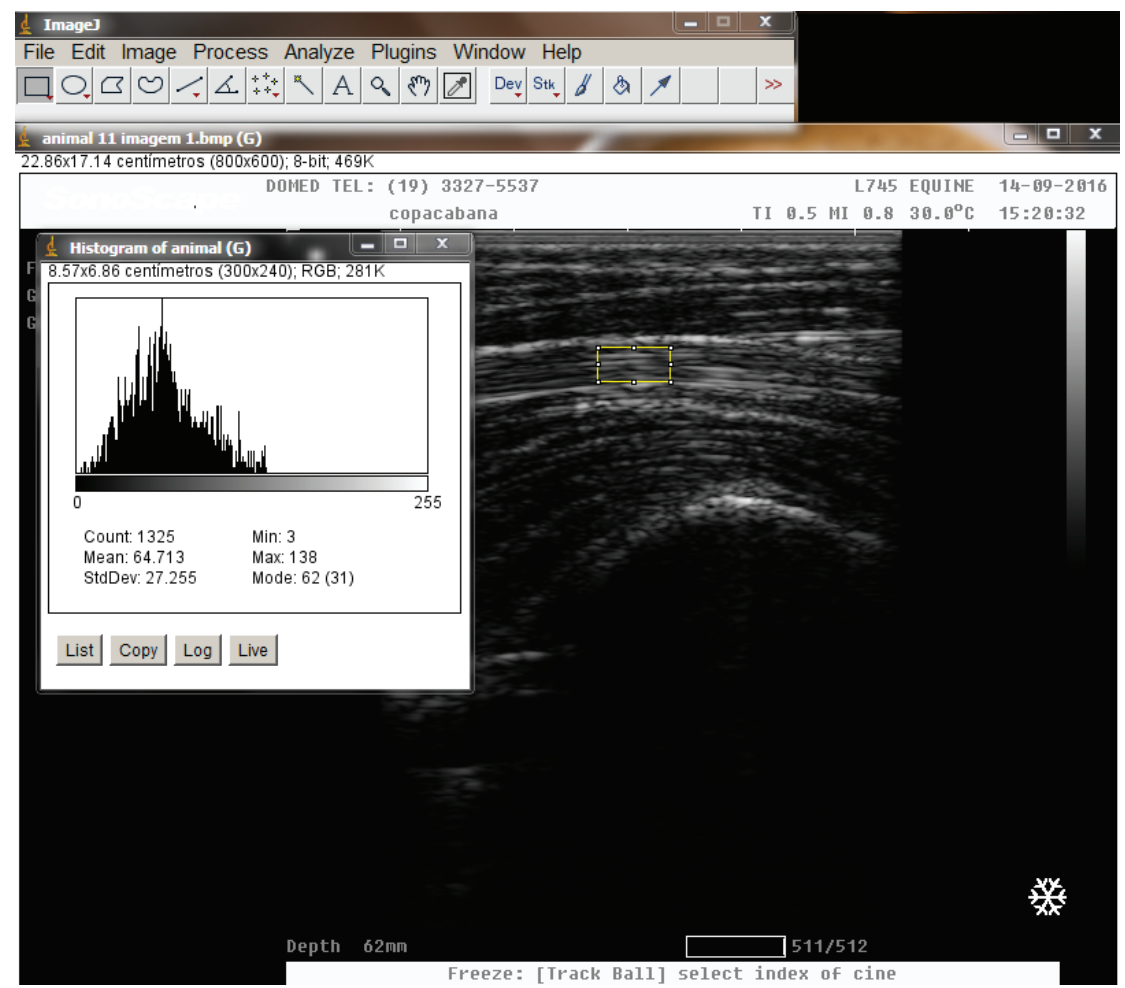

Fig.1. Grayscale histogram performed on the nuchal ligament of a horse to obtain the Mean and Mode variables.

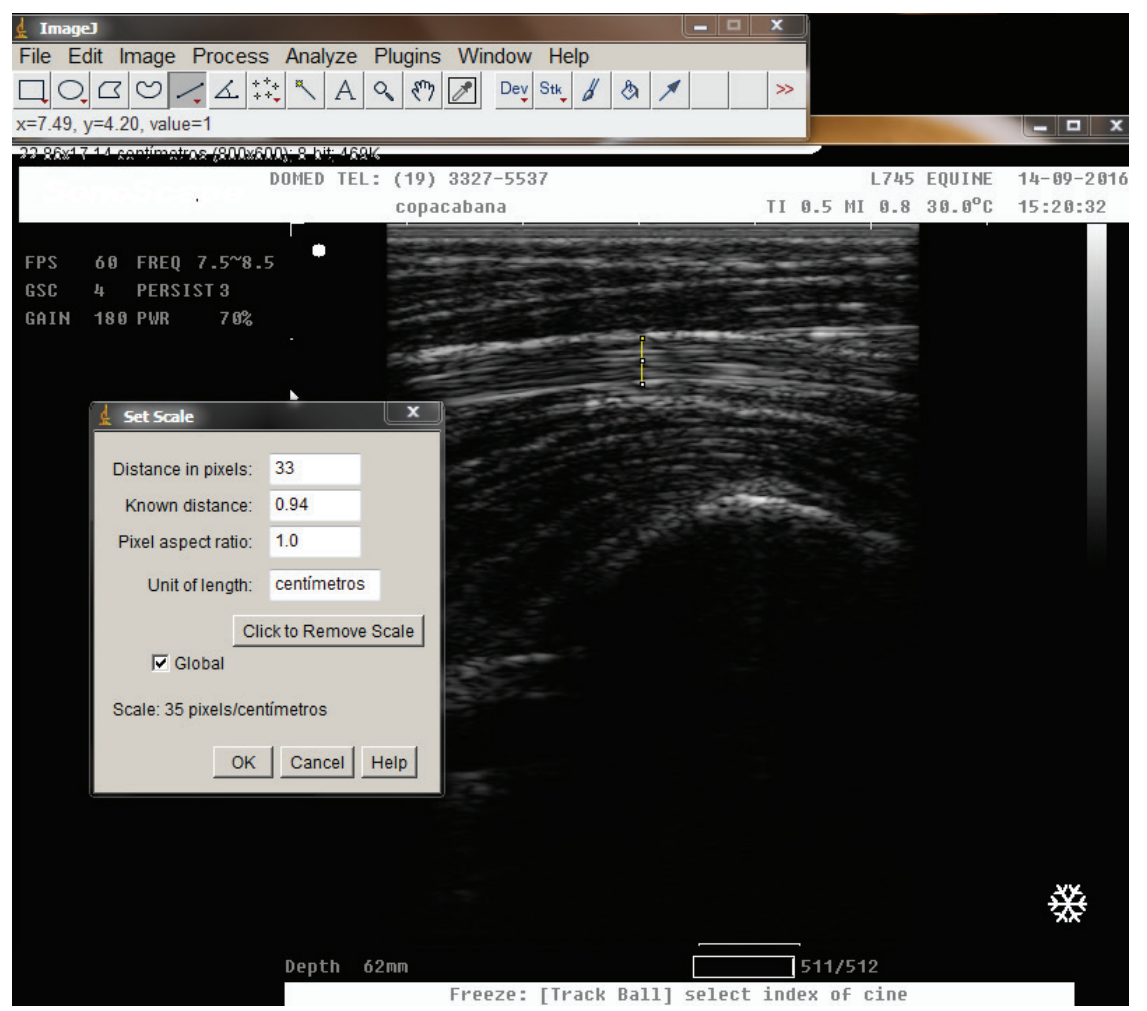

Fig.2. Measurement of the nuchal ligament height on the ultrasound image of a horse to obtain the measurements in centimeters (cm) and distance in pixels.

According to Table 1, Group 2 presented a mean of variables Mean and Mode higher than Group 1 and 3; i.e. echogenicity was higher in this sample. A significant difference was found between the Mean ( $p=0.053)$ and Mode $(p=0.014)$ of the groups.
Table 2 shows the mean and standard deviation of the NL height (cm) ANOVA for each group (1 to 3).

As shown in Table 2, we observed no statistical difference among the groups. 
Table 1. Mean and standard deviation of the GSH variables (Mean and Mode) followed by the ANOVA p-value for the NL of the three groups

\begin{tabular}{ccc}
\hline Group & Mean & Mode \\
\hline 1 & $49.67 \pm 23.86$ & $34.80 \pm 20.91$ \\
2 & $77.42 \pm 10.83$ & $69.04 \pm 10.04$ \\
3 & $64.86 \pm 8.93$ & $60.80 \pm 13.18$ \\
p-value & $0.0533^{*}$ & $0.014^{*}$
\end{tabular}

*p-value $<0.05$.

Table 2. Mean and standard deviation of the NL height (cm) ANOVA for Group 1 to 3

\begin{tabular}{cc}
\hline Group & Average and standard deviation $(\mathrm{cm})$ \\
\hline 1 & $0.984 \pm 0.1128$ \\
2 & $0.834 \pm 0.1258$ \\
3 & $0.864 \pm 0.0357$ \\
p-value & 0.0786 \\
${ }^{*}$ p-value $<0.05$. &
\end{tabular}

\section{DISCUSSION}

The GSH analysis has been reported as a means to overcome variations due to observers' subjectivity (Osawa \& Mori 1996). According to Maeda et al. (1998) and Monteiro et al. (2010), the depth of the region evaluated, the ultrasound system's marks and the gain used in the test do not cause a statistically significant impact on the results obtained by the GSH. In this study, gain was standardized and the same machine was used for all of the exams.

Micklethwaite et al. (2001) have described the efficiency of pixel tone analysis in ultrasound scans, as it allows veterinarians to monitor healing of lesions in tendons and ligaments and to investigate the efficacy of different treatments.

The ultrasound scan was efficient in characterizing the NL echogenicity, which corroborates Langevin et al. (2009) in their evaluation and diagnosis of ligaments and soft tissues adjacent to the spine in humans.

According to Gollob et al. (2002), the NL is a bilobular structure with well-defined edges, spindle-shaped points, and higher echogenicity than the adjacent tissues when examined by ultrasound, characteristics that are similar to those found in this research.

Most studies involving the GSH Mode and Mean variables have found a similarity between the two (Castiglioni 2018, Fogaça 2018). Nevertheless, the present study found a significant difference between these variables among the groups. The Mode did not present confidence in relation to the Mean, which means that the most recurrent gray levels in the image, according to the GSH, did not correspond to the total mean of pixels selected in the image. In view of the difference between the Mode and the Mean, it is preferable to use the Mean to quantify the GSH.

According to Ferreira \& Rasband (2012), the GSH allows for an accurate evaluation of the gray levels found in an area of interest in any image. The analysis of the results of this study in the ultrasound images showed that the NL echogenicity (Mean and Mode) was higher in Group 2 compared to Groups 1 and 3. The echogenicity was probably influenced by the attenuation coefficient of the soft subjacent tissues, such as the surrounding muscles, subcutaneous fatty tissues, and skin, which corroborates Yu et al. (2012) and Hsu et al. (2017). According to Collinger et al. (2010), body weight is indirectly proportional to the echogenicity of the supraspinatus tendon--an observation similar to the findings of this study with regard to the echogenicity of the NL in Group 3. Thus, this correlation is attributed to Group 2.

According to Yu et al. (2012), in human beings, age can have an indirect influence on the echogenicity of the supraspinatus tendon since, older people are more susceptible to lesions, more hypoechogenic and thicker, similar to the findings in Group 3 with regard to echogenicity.

According to Martinoli et al. (1993), the linear echoes of the tendons depend on the acoustic interfaces between the boundaries of the collagen bundles and the endotendinous septum, based on their different histological composition (Martinoli et al. 1993). Extrapolating to the ligaments, we must also consider the histological characteristics that are closely related to the ultrasound image. In this way, as collagen content increases from birth to adulthood, when its contents are relatively stable, and gradually decreases with age (Parry et al. 1978), this might justify the differences in echogenicity found between Group 1 and the others.

The GSH has been shown to be a promising tool for detecting the hypoechogenic aspect of supraspinatus tendinopathy (Hsu et al. 2017), so that it may be strongly recommended for several ligaments of Quarter horses, particularly the NL, for which the literature is scarce.

Free movement of the horses' head and neck would result in measurable changes in the nuchal ligament dimensions (Nestadt et al. 2015). For this reason, the animals in Groups 2 and 3 were haltered and all of them kept their head above the withers. The animals in Group 1, however, were submitted to anesthesia for immobilization during the ultrasound scans.

According to Collinger et al. (2010), there is no correlation between the height of the supraspinatus ligament and health status in humans, and this study did not find a significant difference among the NL heights within the groups. Considering the absence of studies in the literature reviewed on NL GSH in horses and human beings, it is not possible to determine if this difference in echogenicity related to age is present in other breeds and species, which makes it important to conduct further research.

\section{CONCLUSION}

The grayscale histogram (GSH) showed that the nuchal ligament (NL) echogenicity in Quarter horses varies according to age and underlines the efficacy of this tool added to B-mode ultrasound to evaluate the NL.

Conflict of interest.- The authors have no competing interests.

\section{REFERENCES}

Castiglioni M.C.R., Vettorato M.C., Fogaça J.L., Puoli-Filho J.N.P. \& Machado V.M.V. 2018. Quantitative ultrassound of kidneys, liver, and spleen: a comparison between mules and horses. J. Equine Vet. Sci. 70:71-77. <http://dx.doi. org/10.1016/j.jevs.2018.07.011>

Collinger J.L., Fullerton B., Impink B.G., Koontz A.M. \& Boninger M.L. 2010. Validation of greyscale-based quantitative ultrasound in manual wheelchair 
users: relationship to established clinical measures of shoulder pathology. Am. J. Phys. Med. Rehab. 89(5):390-400. <http://dx.doi.org/10.1097/ PHM.0b013e3181d8a238><PMid:20407304>

Ferreira T. \& Rasband W.S. 2012. ImageJ User Guide: ImageJ/Fiji. 1.46. 198p. Available at <https://imagej.nih.gov/ij/docs/guide/user-guide.pdf> Accessed on May 102018

Fogaça J.L. 2018. Estudo comparativo de ultrassonografia modo-B, Doppler e histograma em escala de cinza na avaliação das artérias carótidas comuns em equinos e muares. Master's Thesis, Faculdade de Medicina Veterinária e Zootecnia, Universidade Estadual Paulista de Botucatu. 136p.

Gellman K.S. \& Bertram J.E.A. 2002. The equine nuchal ligament 1: structural and material properties. Vet. Comp. Orthop. Traumatol. 15(1):1-6. <http:// dx.doi.org/10.1055/s-0038-1632705>

Getty R. 1975. Sisson and Grossman's, The Anatomy of the Domestic Animal. 5th ed. W.B. Saunders, Philadelphia, 2095p.

Gollob E., Edinger H., Stanek C. \& Wurnig C. 2002. Ultrasonographic investigation of the atlanto-occipital articulation in the horse. Equine Vet. J. 34(1):44-50. <http://dx.doi.org/10.2746/042516402776181196><PMid:11817551>

Guedes A.G.P. \& Natalini C.C. 2002. Anesthesia horses with colic syndrome: analysis of 48 cases and literature review. Ciência Rural 32(3):535-542. <http://dx.doi.org/10.1590/S0103-84782002000300028>

Henson F.M.D. 2013. Equine Back Pathology: diagnosis and treatment. John Wiley Blackwell, Ames, 280p.

Hsu J.C., Chen P.H., Huang K.C., Tsai Y.H. \& Hsu W.H. 2017. Efficiency of quantitative echogenicity for investigating supraspinatus tendinopathy by the gray-level histogram of two ultrasound devices. J. Med. Ultrason. 44(4):297-303. <http://dx.doi.org/10.1007/s10396-017-0777-6> $<$ PMid:28197744>

Janes J.G., Garrett K.S., McQuerry K.J., Waddell S., Voor M.J., Reed S.M., Williams N.M. \& MacLeod J.N. 2015. Cervical vertebral lesions in equine stenotic myelopathy. Vet. Pathol. 52(5):919-927. <http://dx.doi. org/10.1177/0300985815593127> <PMid:26169385>

König H.E. \& Liebich H.G. 2013. Veterinary Anatomy of Domestic Mammals: textbook and colour atlas. Schattauer Verlag, Stuttigart. 681p.

Langevin H.M., Stevens-Tuttle D., Fox J.R., Badger G.J., Bouffard N.A., Krag M.H., $\mathrm{Wu}$ J. \& Henry S.M. 2009. Ultrasound evidence of altered lumbar connective tissue structure in human subjects with chronic low back pain. BMC Musculoskeletal Disorders 10(1):151. <http://dx.doi.org/10.1186/14712474-10-151><PMid:19958536>

Maeda K., Utsu M. \& Kihaile P.E. 1998. Quantification of sonographic echogenicity with grey-level histogram width: a clinical tissue characterization. Ultrasound Med. Biol. 24(2):225-234.<http://dx.doi.org/10.1016/S03015629(97)00266-4><PMid:9550181>

Marques J.A., Pereira D.A. \& Marques I.C.S. 2009. A combination study of midazolam and detomidine in thepremedication anestesia for the induction of general anestesia with ketamine in foals. Arq. Bras. Med. Vet. Zootec. 61(6):1290-1296. <http://dx.doi.org/10.1590/S0102-09352009000600006>
Martinoli C., Derchi L.E., Pastorino C., Bertolotto M. \& Silvestri E. 1993. Analysis of echotexture of tendons with US. Radiology 186(3):839-843. <http://dx.doi.org/10.1148/radiology.186.3.8430196><PMid:8430196>

Melo U.P., Palhares M.S. \& Ferreira C. 2007. Íleo adinâmico em eqüinos: fisiopatologia e tratamento. Arq. Ciênc. Vet. Zool. UNIPAR 10(1):49-58.

Micklethwaite L., Wood A.K., Sehgal C.M., Polansky M., Dowling B.A., Dart A.J., Rose R.J. \& Hodgson D.R. 2001. Use of quantitative analysis of sonographic brightness for detection of early healing of tendon injury in horses. Am. J. Vet. Res. 62(8):1320-1327. http://dx.doi.org/10.2460/ajvr.2001.62.1320. PMid:11497458.

Monteiro J.N.M., Santos W.G., Oliveira D.C., Borlini D.C., Martins Filho S., Machado F.M. \& Costa F.S. 2010. Ultrassonografia quantitativa do fígado de gatos hígidos: nota prévia. Braz. J. Vet. Res. Anim. Sci. 2038(5):367370. <http://dx.doi.org/10.11606/issn.1678-4456.bjvras.2010.26817>

Nestadt C.L., Lusi C.M. \& Davies H.M.S. 2015. Effect of different head-and-neck positions on nuchal ligament dimensions in fetal foals. J. Equine Vet. Sci. 35(2):153-160. <http://dx.doi.org/10.1016/j.jevs.2014.12.013>

Osawa H. \& Mori Y. 1996. Sonographic diagnosis of fatty liver using a histogram technique that compares liver and renal cortical echo amplitudes. J. Clin. Ultrasound 24(1):25-29. <http://dx.doi.org/10.1002/(SICI)10970096(199601)24:1<25::AID-JCU4>3.0.C0;2-N><PMid:8655663>

Parry D.A.D., Craig A.S. \& Barnes G.R.G. 1978. Tendon and ligament from the horse: an ultrastructural study of collagen fibrils and elastic fibres as a function of age. Proc. R. Soc. London B 203(1152):293-303. <http:// dx.doi.org/10.1098/rspb.1978.0106><PMid:33394>

Ragle C.A. 1993. Head trauma. Vet. Clin. N. Am., Equine Pract. 9(1):171-183. <http://dx.doi.org/10.1016/S0749-0739(17)30422-4>

Ramirez O.J., Joan S. \& Thrall D.E. 1998. Imaging basilar skull fractures in the horse: a review. Vet. Radiol. Ultrasound 39(5):391-395. <http://dx.doi. org/10.1111/j.1740-8261.1998.tb01624.x><PMid:9771589>

Silva E.G., Gonçalves M.T., Pinto S.C., Soares D.M., Oliveira R.A., Alves F.R., Araújo A.V.C. \& Guerra P.C. 2015. Análise quantitativa da ecogenicidade testicular pela técnica do histograma de ovinos da baixada ocidental maranhense. Pesq. Vet. Bras. 35(3):297-303.<http://dx.doi.org/10.1590/ S0100-736X2015000300014>

Swarbrick M.T., Powell S.E. \& Haggett E.F. 2018. Computed tomography of nuchal ligament and semispinalis capitis tendon avulsions in a foal. Equine Vet. Educ. 30(2):70-75. <http://dx.doi.org/10.1111/eve.12627>

Tsukiyama K., Acorda J.A. \& Yamada H. 1996. Evaluation of superficial digital flexor tendinitis in racing horses through gray scale histogram analysis of tendon ultrasonograms. Vet. Radiol. Ultrasound 37(1):46-50. <http:// dx.doi.org/10.1111/j.1740-8261.1996.tb00811.x>

Yu T.Y., Tsai W.C., Cheng J.W., Yang Y.M., Liang F.C. \& Chen C.H. 2012. The effects of aging on quantitative sonographic features of rotator cuff tendons. J. Clin. Ultrasound 40(8):471-478. <http://dx.doi.org/10.1002/jcu.21919> $<$ PMid:22508403> 